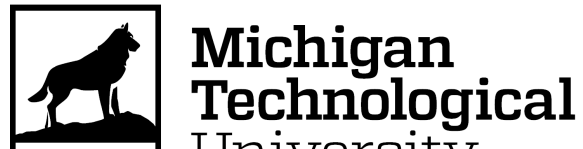 18 8 5
University
}

\section{Michigan Technological University \\ Digital Commons @ Michigan Tech}

Department of Geological and Mining

Engineering and Sciences Publications

Department of Geological and Mining

Engineering and Sciences

9-1982

\section{Research on atmospheric volcanic emissions: An overview}

James P. Friend

Drexel University

Alan R. Bandy

Drexel University

Jarvis L. Moyers

University of Arizona

William H. Zoller

University of Maryland at College Park

Richard E. Stoiber

Dartmouth College

See next page for additional authors

Follow this and additional works at: https://digitalcommons.mtu.edu/geo-fp

Part of the Geology Commons, Mining Engineering Commons, and the Other Engineering Commons

\section{Recommended Citation}

Friend, J. P., Bandy, A. R., Moyers, J. L., Zoller, W. H., Stoiber, R. E., Torres, A. L., Rose, W. I., McCormick, M. P., \& Woods, D. C. (1982). Research on atmospheric volcanic emissions: An overview. Journal of Geophysical Research, 9(9), 1101-1104. http://dx.doi.org/10.1029/GL009i009p01101

Retrieved from: https://digitalcommons.mtu.edu/geo-fp/146

Follow this and additional works at: https://digitalcommons.mtu.edu/geo-fp

Part of the Geology Commons, Mining Engineering Commons, and the Other Engineering Commons 


\section{Authors}

James P. Friend, Alan R. Bandy, Jarvis L. Moyers, William H. Zoller, Richard E. Stoiber, Arnold L. Torres, William I. Rose, M. Patrick McCormick, and David C. Woods 


\title{
RESEARCH ON ATMOSPHERIC VOLCANIC EMISSIONS: AN OVERVIEW
}

\author{
James P. Friend, Alan R. Bandy \\ Department of Chemistry, Drexel University, Philadelphia, PA 19104 \\ Jarvis L. Moyers \\ Department of Chemistry, University of Arizona, Tucson, AZ 85721 \\ William H. Zoller \\ Department of Chemistry, University of Maryland, College Park, MD 20742 \\ Richard E. Stoiber \\ Department of Earth Sciences, Dartmouth College, Hanover, NH 03755 \\ Arnold L. Torres \\ NASA, Wallops Flight Center, Wallops Island, VA 23337 \\ William I. Rose, Jr.
}

Department of Petrology, Michigan Technological University, Houghton, MI 49931

M. Patrick McCormick and David C. Woods

NASA, Langley Research Center, Hampton, VA 23665

\begin{abstract}
The project "Research on Atmospheric Volcanic Emissions" is a unique effort by NASA and university scientists to investigate the detailed chemical nature of plumes from volcanic eruptions. The major goals of the project are to: 1) understand the impact major eruptions will have on atmospheric chemistry processes, 2) understand the importance of volcanic emissions in the atmospheric geochemical cycles of selected species, 3) use knowledge of the plume chemical composition to diagnose and predict magmatic processes. Project RAVE's first mission used the NASA Lockheed Orion P-3 outfitted with equipment to measure concentrations of the gases $\mathrm{SO}_{2}, \mathrm{OCS}, \mathrm{H}_{2} \mathrm{~S}, \mathrm{CS}_{2}, \mathrm{NO}, \mathrm{O}_{3}$ and trace elements in particles in Mt. St. Helens' plume on September 22, 1980. Measurements of $\mathrm{SO}_{2}$ column densities in the plume permitted calculations of $\mathrm{SO}_{2}$ fluxes. This article is an overview of the first experimental design factors and performance of the initial RAVE experiment.
\end{abstract}

\section{Introduction}

Volcanic emissions can play an important role in the chemistry of the stratosphere and troposphere. There exists little data in the form of coordinated, simultaneous measurements of several species which provide quantitative information on composition and chemical reactions. The reactive gases (those containing sulfur, nitrogen and halogens) and particles of volcanic origin (primary and secondary) have the potential to influence climate. They also may affect atmospheric chemistry through radical reactions and formation of acidic and aerosol constituents.

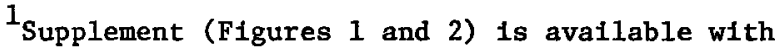
entire article on microfiche. Order from American Geophysical Union, 2000 Florida Avenue, N.W., Washington, D.C. 20009. Document L82-004; $\$ 1.00$. Payment must accompany order.
}

Copyright 1982 by the American Geophysical Union.

Paper number 2L1186.

$0094-8276 / 82 / 002 L-1186 \$ 3.00$
Atmospheric abundances and the geochemical cycle of certain volatile compounds and elements may be largely influenced or entirely controlled by magmatic sources. Coderre and Steinthorsson (1977) have shown that the Icelandic volcanoes can be a significant source for mercury in the atmosphere. Rasmussen (1982) has reported that reduced sulfur species ( $C_{2}$, OCS) were emitted and/or formed in the Mt. St. Helens eruptions of 1980. Gandrud and Lazrus (1981), and Cadle (1975) have shown that the halogen emissions from volcanoes may be quite important to the stratospheric burden of these elements. Mroz and Zoller (1975), Lepel et al. (1978), and Cadle et al. (1973) have measured several trace elements in Icelandic, Hawailan and Alaskan volcanoes. These studies demonstrate that volcanic emissions are atmospheric sources of several species and, in some cases, may well be the dominant source. Better estimates of the magnitude and variability of volcanic emissions are required if the importance of this natural source of atmospheric constituents and the resulting effect on atmospheric chemistry and burdens of species are to be elucidated. Stoiber and Rose (1974) and Rose (1977) have presented evidence that atmospheric emissions from various eruptive phases of volcanoes can be used as an indicator of magmatic processes. To date, halogen, sulfur and carbon gases have been primarily used for such studies. Additional information on the composition of the gaseous and particulate phases and physical characteristics of the particles generated in volcanic plumes is expected to expand the basis for diagnosing the major processes in volcanism.

The principal motive behind the project "Research on Atmospheric Volcanic Emissions" (RAVE) is to improve knowledge of both geological and chemical phenomena attending these emissions by means of comprehensive instrumentation on board a research aircraft making simultaneous measurements of plume constituents. This report describes the equipment and procedures used in the RAVE field study of Mt. St. Helens' plume and provides an overview of the results. 
TABLE 1. Methods of Measurement and Species Monitored Aboard the P-3 Volcano Plume Sampling Program

SPECIES MEASUREMENT METHOD

\begin{tabular}{|c|c|}
\hline $\mathrm{SO}_{2}, \mathrm{CS}_{2}, \mathrm{H}_{2} \mathrm{~S}, \mathrm{OCS}$ & Gas Chromatography (FPD) \\
\hline $\begin{array}{l}\mathrm{SO}_{2} / \text { Total Sulfur } \\
\text { (Gâseous) }\end{array}$ & $\begin{array}{l}\text { Flame Photometric Detector } \\
\text { (Continuous) }\end{array}$ \\
\hline $\mathrm{SO}_{2}$ & COSPEC (Remote Sensing) \\
\hline NO & $\begin{array}{l}\text { Chemiluminescence } \\
\text { (Continuous) }\end{array}$ \\
\hline $\mathrm{O}_{3}$ & UV Absorption (Continuous) \\
\hline $\begin{array}{l}\text { Acidic Gases } \\
\left(\mathrm{SO}_{\mathrm{x}}, \mathrm{Hx}, \mathrm{HNO}_{3}\right)\end{array}$ & $\begin{array}{l}\text { Coated Filters, Nylon Filters } \\
\text { (Integrated Sample) }\end{array}$ \\
\hline $\begin{array}{l}\text { Particles } \\
\text { (Chemistry) }\end{array}$ & $\begin{array}{l}\text { Filters, Cascade Impactors/NAA, } \\
\text { IC, SEM (Integrated Sample) }\end{array}$ \\
\hline $\begin{array}{l}\text { Particles } \\
\text { (Mass) }\end{array}$ & $\begin{array}{l}\text { LIDAR (Remote Sensing) } \\
\text { Quartz Crystal, Micro- } \\
\text { balance (Semi-Continuous) }\end{array}$ \\
\hline
\end{tabular}

\section{Instrumentation and Methodology}

In June 1980 the investigators began outfitting the NASA Lockheed Orion P-3 with chemical measurement and sampling equipment designed specifically for measuring several important species in volcanic plumes. The species selected for analysis (and methods employed) in this initial phase of the project are listed in Table 1 . The selection was made on the basis of the known or inferred importance of the species to atmospheric chemistry or their usefulness as indicators of geological processes. It is anticipated that additional species will be measured in later phases of this research project. All equipment is designed to be used on either the P-3 or the NASA Lockheed Electra. The measurement systems provide complimentary information about plume composition and the flux of emissions. The in situ chemical measuring devices were calibrated in flight and all instruments were zeroed in flight.

Three of the instruments measured sulfur gases. A correlation spectrometer (COSPEC IV, Barringer Ltd., Toronto, Canada) measured the column density of $\mathrm{SO}_{2}$ in a vertical column viewed through a quartz window mounted in the top of the fuselage. A flame photometric detector (Model 285 FR, Meloy Laboratories, Inc., Springfield, VA), configured to operate at a constant pressure of 800 torr, measured continuously the total sulfur concentration within the plume. A dual-channel gas chromatograph made in-flight measurements of $\mathrm{SO}_{2}, \mathrm{H}_{2} \mathrm{~S}, \mathrm{CS}_{2}$ and OCS in the plume by direct injection of sample air. Particle measurement systems aboard the aircraft included: 1) integrating filter samplers; 2) semi-continuously operating multistage impacting quartz crystal microbalance (Model 1004, California Measurements, San Rafael, CA); and 3) a remote sensing LIDAR. Filter samples were returned to the participating laboratories for chemical analysis by neutron activation analysis, ion chromatography, scanning electron microscopy and energy dispersive $x-r a y$ analysis. Filtration sampling ports were constructed to accommodate packages of up to four filters of absorbent traps. The first filter was used for aerosol collection and analysis and subsequent filters of absorbents were used to collect vapor phase substances. Nylon and/or base-treated filters were used to collect reactive acidic gases. Charcoal and other absorbents (e.g., gold beads) were used to collect volatile elements and their compounds (e.g., $\mathrm{Hg}, \mathrm{As}, \mathrm{Se}$ ).

\section{Field Measurements}

The previously described instruments were installed aboard the $\mathrm{P}-3$ and flight-tested during the summer of 1980. On September 22, 1980 a fourhour mission was flown out of Portland, $O R$ to probe and study the Mt. St. Helens plume. At that time, Mt. St. Helens was at a relatively quiescent phase between the major eruptions of July 22, 1980 and October 15, 1980. During September the daily $\mathrm{SO}_{2}$ fluxes from Mt. St. Helens, as measured by Harris et al (1980), ranged between 130 and 3900 tonnes per day. September 22, 1980 was an overcast day with a cloud ceiling of approximately $3000 \mathrm{~m}$. Winds were from the northwest and brisk $(7-12 \mathrm{~m} / \mathrm{sec})$.

The volcanic plume was at a height of about $2400 \mathrm{~m}$ which is about the height of the crater rim at the southerly edge. The plume appeared to be well-formed, bent over at the top of the crater rim, and rapidly diluted downstream by mixing in the relatively strong winds. The top of the mountain was obscured by clouds during the mission, though downwind the plume was distinctly visible extending to about $30 \mathrm{~km}$ distance and below the prevailing cloud ceiling of $3 \mathrm{~km}$. The initial sighting of the plume gave evidence that it had some thermal buoyancy for at least a portion of it had penetrated the clouds over the peak. The sam-

TABLE 2. Description of Mt. St. Helens Plume on September 22, 1980.*

\begin{tabular}{cll}
\hline $\begin{array}{c}\text { Period } \\
\text { (GMT) }\end{array}$ & $\begin{array}{l}\text { Height of Plume } \\
\text { Base (m) } \\
(17-21 \mathrm{~km} \\
\text { downwind) }\end{array}$ & $\begin{array}{l}\text { Approximate } \\
\text { Thickness (m) } \\
(17-21 \mathrm{~km} \\
\text { downwind) }\end{array}$ \\
\hline $1450-1735$ & 2290 & 460 \\
$1840-1905$ & $1520-1950^{+}$ & $1220-790$ \\
\hline
\end{tabular}

* Characteristics of the plume derived from COSPEC measurements of $\mathrm{SO}_{2}$ column abundances during crosswind traversals at various elevations below, within and above the plume.

+ The plume was seen (visually) to be above $1520 \mathrm{~m}$. The COSPEC data did not allow for a definite assignment of the base altitude because of flight altitude gap between $5000 \mathrm{ft}$. and 7000 $f t$. 
pling operations consisted of a series of crosswind and upwind/downwind (referred to as coaxial) traverses. Crosswind traverses were performed under, within, and above the plume. This series permitted analysis of the COSPEC data of $\mathrm{SO}_{2}$ column density above the aircraft to delineate the vertical and horizontal extent of the plume (at two distances downwind). The crosswind traversals under the plume provided the COSPEC data from which $\mathrm{SO}_{2}$ flux estimates were made (cf Casadevall et. al., 1981). Table 2 provides a description of the plume during the period of flight operations. Table 3 shows apparent plume widths and $\mathrm{SO}_{2}$ fluxes calculated from the COSPEC data. In all, 26 traverses (both crosswind and upwind/downwind) of the plume were performed during this mission.

\section{Results and Discussion}

Even though the weather and plume conditions were not ideal, an extensive amount of chemical information was obtained on this mission. The aircraft served as an excellent platform for both in-plume and background monitoring and sampling. All onboard instrumentation operated without major problems and excellent results were obtained. A high degree of consistency between the different measuring systems becomes evident on examination of the collected data. A summary comparison of results from the three sulfur measuring systems is provided in Table 4. Figure 1 shows the plume profile at $20 \mathrm{~km}$ from the volcano as synthesized from continuous sulfur monitor and correlation spectrometer results from cross plume traverses at different altitudes. Each sulfur instrument had an independent sampling (view) port. From these data the $\mathrm{SO}_{2}$ flux from Mt. St. Helens' was estimated to be 900 tonnes per day on September 22 , 1980 (See Table 3). Sulfur dioxide was the predominant gaseous species with the reduced sulfur species being less than about $10 \%$ of the total sulfur emissions. A detailed report of sulfur compound and NO concentrations in the plume is

TABLE 3. Apparent Plume Widths and $\mathrm{SO}_{2}$ Fluxes as Determined from COSPEC Measurements.

\begin{tabular}{|c|c|c|c|c|c|}
\hline $\begin{array}{l}\text { Run Number } \\
\text { Time }{ }^{+} \text {(GMT) } \\
\text { Altitude ( } f t)\end{array}$ & $\begin{array}{c}2 \\
1659 \\
7500\end{array}$ & $\begin{array}{c}3 \\
1708 \\
7000\end{array}$ & $\begin{array}{c}4 \\
1714 \\
6000\end{array}$ & $\begin{array}{c}5 \\
1721 \\
5000\end{array}$ & $\begin{array}{r}15 \\
1844 \\
5000\end{array}$ \\
\hline Downwind & & & & & \\
\hline $\begin{array}{l}\text { Distance } \\
\text { Apparent Plume }\end{array}$ & 17.5 & 19.4 & 17.4 & 21 & 20 \\
\hline $\begin{array}{l}\text { Width (km) } \\
19 \\
\text { Estimated SO }\end{array}$ & 32 & 30 & 21 & 25 & \\
\hline $\begin{array}{l}\text { Flux (metric } \\
\text { tons per day) }\end{array}$ & 920 & 920 & 940 & 910 & 940 \\
\hline
\end{tabular}

+ Times refer to approximate mid-points of the crosswind traversals.

* The fluxes were calculated using the crosswind integrated column abundances determined by the COSPEC and multiplying by an estimated average wind of $9.5 \mathrm{~m} 5^{-1}$. This is the average of many values of wind speed as determined using inertial navigation measurements. The wind speed in the plume varied by about $\pm 20 \%$ in average.
TABLE 4. Comparative Instrument Performance of Three Sulfur Measurement Systems

\begin{tabular}{lccc}
\hline $\begin{array}{l}\text { Instru- } \\
\text { ment }\end{array}$ & $\begin{array}{c}\text { Sulfur concentrations } \\
\text { in plume } \\
\text { Average }\end{array}$ & $\begin{array}{l}\text { Mpb) } \\
\text { Maximum }\end{array}$ & $\begin{array}{c}\text { Calculated } \\
\mathrm{SO}_{2} \text { Flux } \\
\text { (Tonnes/day) }\end{array}$ \\
\hline FPD & $100-200$ & 350 & $800-2000$ \\
GC & $100-250$ & 400 & NA \\
COSPEC & $50-200 *$ & NA & $900-1200$ \\
\hline
\end{tabular}

* Concentration inferred from information on column abundances at various heights below and within the plume.

provided by Bandy et al., (1982) in a companion paper.

One important finding of this mission was the identification of the volcano as a small but measurable source of NO (see Bandy et al., 1982). A high degree of correlation was seen between the continuous sulfur monitor and the continuous NO monitor. Figure 2 presents a scattergram of average NO plume concentration versus average total sulfur gas concentration (determined by the University of Arizona FPD) for eight (8) cross plume traverses. The linear correlation coefficient for these eight measurements is 0.9 . The average No/total S-gas ratio is $(1.6+0.3) \times 10^{-3}$. This is in agreement with the result of Bandy et al., (1982) to within the standard error of each determination (when total $\mathrm{S}$ is corrected for the $\mathrm{H}_{2} \mathrm{~S}$ component as estimated by Bandy et al.., 1982). These data then imply that during this mission the volcanic NO flux was about 1-2 tonnes per day. This raises the questions of the origin of the NO and, because of its effect on $\mathrm{O}_{3}$, the potential impact large scale eruptions have on the stratospheric chemical cycles. Since, at the time of the measurements, the emissions were undoubtedly free from contamination by overlying soil and the temperature of the gases within the lava dome was too low for the oxidation of atmospheric $\mathrm{N}_{2}$ upon emission, it seems reasonable to suppose that the NO might have originated from bound nitrogen in ancient sediments which were recycled in the activity associated with the production of the magma. Additional measurements of this type should provide more important information for the further elucidation of these questions.

The $\mathrm{O}_{3}$ measurements indicated a background of about 25 ppbv with no measurable depletion caused by the plume. The absence of an $\mathrm{O}_{3}$ depletion is commensurate with the low No concentrations and may indicate low heterogeneous conversion rates for the sulfur gases. Rasmussen et al.. (1976) measured strong $\mathrm{O}_{3}$ depletions in the plume of Mt. St. Augustine in 1976 ( $\mathrm{SO}_{2}$ concentrations were 2-5 times larger than measured here). A discussion of the redox chemistry of volcanic plumes is beyond the scope of this paper. However, we suggest that $\mathrm{O}_{3}$ measurements may be a useful indicator of plume chemistry.

Several integrated particulate and reactive gas samples were collected on the September 22 , 1980 mission. Details and discussions of analysis and results are provided in companion papers (Phelan et al., 1982; Rose et al., 1982). A high degree of correlation was found between several species measured in these samples and the continu- 
ous monitoring devices. It was found that the aerosol was enriched in volatile trace elements (relative to Mt. St. Helens ash deposited in Pullman, WA). Comparison of the concentrations of some trace volatile elements with the $\mathrm{SO}_{2}$ concentrations permitted estimates of their fluxes. Measurements of this type will provide information on the importance of volcanic emissions in the cycling of volatile trace elements through the atmosphere.

The results from the September 1980 RAVE Mt. St. Helens' volcano mission demonstrate that a four-engine turbo-prop is an excellent airborne laboratory for making detailed measurements of volcanic plumes. Both the Lockheed $\mathrm{P}-3$ and the Electra have several attractive features for these types of studies. Power, maneuverability, payload and range make this type of aircraft almost ideal for research on atmospheric volcanic emissions. With this sampling platform it is possible to accommodate several simultaneous experiments which can provide detailed information about the plume chemistry and physics. In addition, internal cross checks on data permit evaluation of experiment validity and consistency.

\section{Summary and Conclusions}

The initial RAVE experiment was conducted on September 22, 1980 at Mt. St. Helens' volcano. Aircraft and equipment performance exceeded expectations in the provision of useful data on the plume chemistry. All monitoring and sampling systems performed with internal consistency between systems. This initial investigation has yielded estimates of the volcanic emission fluxes of several species of importance to atmospheric chemistry. The samples and data collected in this experiment serve as new and useful indicators of volcanological processes. Significant results obtained from this study include: 1) The first direct measurement of a volcanic source for NO; 2) The measurement of the Mt. St. Helens source strength for several volatile trace elements of atmospheric importance: 3) The simultaneous measurement of the sulfur species present in the emissions; and 4) The evaluation of the volcanic process itself through the morphological and chemical examination of primary and secondary particles present in the plume.

Acknowledgements. The work reported in this and the other RAVE papers referred to herein was sponsored by the National Aeronautics and Space Administration under Grant No. NAG 1-200. The investigators in this project (the authors of this paper) acknowledge gratefully the support and enthusiastic participation of Mssrs. C. R. Allen and R. R. Roehren, pilots, Mr. Roger L. Navarro, project engineer and members of the $\mathrm{P}-3$ crew from NASA/Wallops Island, VA

\section{References}

Bandy, A.R., P.J. Maroulis, L.A. Wilner and A.L. Torres, Estimates of the fluxes of $\mathrm{NO}, \mathrm{SO}_{2}, \mathrm{H}_{2} \mathrm{~S}$,
$\mathrm{CS}_{2}$ and OCS from Mt. St. Helens deduced from insitu plume concentration measurements, this issue.

Cadle, R.D., Volcanic emissions of halides and sulfur compounds to the troposphere and stratosphere, J. Geophys. Res., 80, 1650, 1975.

Cadle, R.D., A.F. Wartburg, W.H. Pollock, B.W. Gandrud and J.P. Shedlousky. Trace constituents emitted to the atmosphere by Hawaiian volcanoes, Chemosphere, 6, 231-234, 1973.

Casadevall, T.J., D.A. Johnston, D.M. Harris, W.I. Rose, Jr., L.L. Malinconico, R.E. Stoiber, T.J. Bornhorst, S.N. Wills, L. Woodruff, J.M. Thompson, $\mathrm{SO}_{2}$ emission rates at Mt. St. Helens from March 29 through December, 1980, USGS Professional Paper 1250, pp. 193-200, 1981.

Coderre, J.A. and S. Steinthorsson, Natural concentrations of mercury in Iceland, Geochimica et Cosmochimica Acta, 41, 419, 1977 .

Gandrud, B.W. and A.L. Lazrus, Filter measurements of stratospheric sulfate and chloride in the eruption of Mount St. Helens, Science, 211, $827,1981$.

Harris, D.M., T.J. Casadevall, D.A. Johnston, W.I. Rose, T.J. Bornhorst, R.E. Stoiber, L.L. Malinconico and S.N. Williams, Contributions of $\mathrm{CO}_{2}$ and $\mathrm{SO}_{2}$ to the atmosphere from volcanic activity at Mount St. Helens. Presented at Symposium on Mount St. Helens Eruption, IFAORS, Washington, D.C., November 1980.

Lepel, E.A., K.M. Stefansson and W.H. Zoller, The enrichment of volatile elements in the atmosphere by volcanic activity: Augustine volcano $1976, \mathrm{~J}$. of Geophys. Res., 83, 6213, 1978.

Mroz, E.J. and W.H. Zoller, Composition of atmospheric particulate matter from the eruption of Heimaey, Iceland, Science, 190, 461, 1975.

Phelan, J.M., D.L. Finnegan, D.S. Ballantine, W.H. Zoller, M.A. Hart and J.L. Moyers, Airborne aerosol measurements in the quiescent plume of Mount St. Helens: September 1980, this issue.

Rasmussen, R.A., M.A.K. Khalil, R.W. Dalluge, S.A. Penkett and $B$. Jones, Carbonyl sulfide and carbon disulfide from the eruptions of Mount $S t$. Helens, Science, 215, 665, 1982.

Rasmussen, R.A., R. Stordour, J.L. Moyers, J.G. Eckhardt and W.H. Zoller, Sulfur and ozone distributions in a 1976 Augustine volcano plume, presented at American Geophysical Union Spring Annual Meeting, Washington, D.C., April 1976.

Rose, W.I., Scavenging of volcanic aerosols by ash: atmospheric and volcanologic implications, Geology, 5, 621, 1977.

Rose, W.I.. R.L. Chuan and D.C. Woods, Small particles in active and passive plumes of Mount St. Helens, August - September 1980, this issue.

Stoiber, R.E. and W.I. Rose, Fumarolic incrustations at active Central American volcanoes, Geoch. Cosmoch. Acta, 38, 495, 1974.

(Recelved May 17, 1982; accepted August 3, 1982.) 